\title{
Nickel Impregnated Cerium-Doped Strontium Titanate Fuel Electrode: Direct Carbon Dioxide Electrolysis and Co-Electrolysis
}

\author{
Denis J. Cumming, ${ }^{\mathrm{z}}$ Alison R. Thompson, ${ }^{*}$ and Rachael H. Rothman \\ Department of Chemical and Biological Engineering, University of Sheffield, Sheffield, S1 3JD, United Kingdom
}

\begin{abstract}
Direct electrolysis of carbon dioxide and co-electrolysis of steam and carbon dioxide offers an efficient and effective method to produce $\mathrm{CO}$ or syngas and also utilizes $\mathrm{CO}_{2}$ in a carbon-neutral fuel cycle. Here we report the use of composite fuel electrode containing a $\mathrm{Sr}_{0.7} \mathrm{Ce}_{0.2} \mathrm{TiO}_{3 \pm \delta}(\mathrm{SCT})$ and $\mathrm{Sm}_{0.20} \mathrm{Ce}_{0.80} \mathrm{O}_{2-\delta}(\mathrm{SDC})$ backbone which has been infiltrated with nickel nitrate and decomposed to form nickel surface decoration on the ceramic scaffold. Maximum cell current during electrolysis at $850^{\circ} \mathrm{C}$ was $263 \mathrm{mAcm}^{-2}$ and $192 \mathrm{mAcm}^{-2}$ at $1.8 \mathrm{~V}$ for co-electrolysis and $\mathrm{CO}_{2}$, respectively. The infiltrated nickel particles provided a large surface area and enhanced activity during electrolysis. These findings demonstrate that Ce-doped titanate mixed conductors combined with low volume nickel additions are promising next-generation electrode materials for solid oxide electrolysis cells.

(C) The Author(s) 2016. Published by ECS. This is an open access article distributed under the terms of the Creative Commons Attribution 4.0 License (CC BY, http://creativecommons.org/licenses/by/4.0/), which permits unrestricted reuse of the work in any medium, provided the original work is properly cited. [DOI: 10.1149/2.0081611jes] All rights reserved.
\end{abstract}

Manuscript submitted March 15, 2016; revised manuscript received May 31, 2016. Published June 8, 2016. This paper is part of the JES Focus Issue on Electrolysis for Increased Renewable Energy Penetration.

Fossil-based fuels remain the key component in the global energy mix. Their continued use leads to carbon dioxide emissions which contributes to climate change. To mitigate emissions, renewable energy sources (wind, solar and tidal, biomass etc.) have seen increased popularity. One of the key challenges facing the uptake of renewable electrical generation technologies is a way to store the intermittent electricity these tend to generate. Another complicating factor is the role fossil fuels play in transportation where alternatives such as hydrogen are limited by infrastructure and viable carbonfree hydrogen generation technology. Both of these issues can be addressed by producing liquid hydrocarbon fuel from renewable or excess grid electricity. ${ }^{1}$ High temperature electrolysis of steam and carbon dioxide has been shown an efficient and scalable route to producing syngas which will readily convert to a versatile range of downstream hydrocarbons. ${ }^{2-6}$ Use of a state-of-the-art solid oxide electrolysis cell with nickel-YSZ composite electrode for $\mathrm{CO} / \mathrm{CO}_{2}$ has also been demonstrated as a means of directly utilizing and recycling captured carbon dioxide rather than capture and storage. However, using traditional nickel-based composite electrodes showed relatively high levels of passivation due to sulfur impurities in the gas feed streams.?

The need for a robust alternative to nickel-composite electrode materials has been widely documented for solid oxide fuel cells. ${ }^{8}$ Instability under oxidizing conditions, ${ }^{9-11}$ nickel agglomeration ${ }^{12,13}$ and deleterious reactions with sulfur ${ }^{14}$ and carbon ${ }^{15}$ are often cited as the main problems facing Ni-composite electrodes. Other metals (Cobalt ${ }^{16-18}$ and Copper ${ }^{19,20}$ for example) have been proposed as a nickel replacement showing reasonable success. However the goal of recent research has been to replace the metal with a suitable ceramic material, either as a single phase material or as part of a composite. Ceramic materials offer several advantages over metal-based materials for the fuel electrode in solid oxide cells. They can provide a stable backbone that does not sinter during operation, have dimensional stability during re-oxidation cycles and are tolerant to sulfur. Several families of ceramic materials have been suggested as alternate electrodes. ${ }^{21}$ Titatante-based materials are one promising candidate. Under reducing conditions, $\mathrm{SrTiO}_{3}$ (STO) becomes an electronic conductor due to the reduction of $\mathrm{Ti}^{4+}$ to $\mathrm{Ti}^{3+}$. Donor doping on the A or B-site with $\mathrm{La} / \mathrm{Y}$ or $\mathrm{Nb}$ respectively significantly increases the electronic conductivity. Depending on the oxygen partial pressure, the compensation mechanism in donor-doped materials can

*Electrochemical Society Student Member.

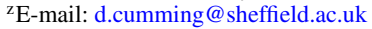

switch between Sr-vacancies under oxidizing conditions and electrons under reducing conditions (from the reduction of $\mathrm{Ti}^{4+} / \mathrm{Ti}^{3+}$ ). Typically these materials are prepared with a small degree of cation non-stoichiometry to maintain a single phase during synthesis. In the case of La-doped STO it has been found experimentally that oxygen excess can be accommodated by the formation of layered intergrowths rich in $\mathrm{La}^{22} \mathrm{Nb}, \mathrm{Y}$ and Ce doped materials do not seem to support intergrowth structures and tend to precipitate second phases if the stoichiometry, defect regime and processing conditions are not coordinated.

Electrochemical cell performance has been reported for Y, La and $\mathrm{Nb}$-doped titanate materials ${ }^{23,24}$ with encouraging testing results, however, many of the titanate materials show negligible catalytic activity. ${ }^{25}$ Significant performance improvements have been shown in electrodes based on a titanate backbone where the microstructure has been decorated with metal nanoparticles. ${ }^{25,26}$ Typically these particles are formed by the infiltration of a metal salt, followed by decomposition. Another novel method of forming a surface nanoparticle is by adding an additional component to the titanate that will become unstable during operation and precipitate from the backbone structure. ${ }^{27,28}$ State-of-the-art decorated titanate electrode materials now represent a viable alternative to the traditional nickel cermet electrode for fuel cell applications.

Electrochemical performance of titanate-based materials under electrolysis conditions has only very recently been reported. ${ }^{29-33}$ In previous publications we reported the structural ${ }^{34}$ and electrical properties ${ }^{35}$ of Ce-doped $\mathrm{SrTiO}_{3}$ (SCT). This paper investigates the potential of Ce-doped titanate compositions as an alternative to existing titanate-based materials for electrolysis cells. Of particular interest is the possibility these materials offer for the electrolysis of dry $\mathrm{CO}_{2}$ by using a mixed conducting titanate scaffold infiltrated with nickel nanoparticles. Nickel was chosen as it is a good catalyst, does not react with other cell materials, and allows comparison with commonly used electrode materials. We demonstrate for the first time the potential of new titanate-based composition as a scaffold for metal catalysts in new electrolysis applications.

\section{Experimental}

Sample preparation.-Samples were prepared by mixing oxides $\mathrm{TiO}_{2}$ (99.8\%, Aldrich), $\mathrm{SrCO}_{3}$ (99+\%, Aldrich) and $\mathrm{CeO}_{2}(99+\%$, Aldrich) and calcining at high temperature as described previously. ${ }^{35}$ Electrolyte supported cells were fabricated on dense $200 \mu \mathrm{m}$ thick 8 YSZ foils (Kerafol) by screen printing using an ink containing 
Terpineol, ethylcelulose and KD1 as solvent, binder and dispersant respectively. SCT powder and nano-sized samaria-doped ceria (Fuel Cell Materials) were ball milled for $24 \mathrm{hrs}$ in acetone along with dispersant and zirconia milling media. The milled slurry was transferred to a polypropylene pot and the binder and solvent were added. The ink was mixed using an asymmetric shear mixer (DAC250, Speedmixer). Excess acetone was removed at $70^{\circ} \mathrm{C}$ and the ink mixed at regular intervals until the desired viscosity was obtained. Electrodes were printed on electrolyte supports using a semi-automatic screen printer (Model $247, \mathrm{DEK}$ ), dried at $130^{\circ} \mathrm{C}$ and then sintered in air at $1350^{\circ} \mathrm{C}$ for $4 \mathrm{hrs}$. The oxygen electrode consisted of commercial LSM-YSZ power (Fuel Cell Materials) made into an ink and printed using the same process described above. Oxygen electrode was sintered at $1100^{\circ} \mathrm{C}$ in air.

Infiltration was performed on the SCT fuel electrode using a nickel nitrate-ethanol solution. The solution was added drop-wise until the electrode was wetted and then dried in an oven at $180^{\circ} \mathrm{C}$ for 5 mins. This process was repeated five times. The nitrates were decomposed by firing at $500^{\circ} \mathrm{C}$ for $2 \mathrm{hrs}$ in air. Silver-palladium, 70-30 wt\% (Gwent Electronic Materials) current collector grids were printed onto both electrodes and sintered in-situ during cell testing.

Sample characterization.-Phase purity was checked using a STOE STADI P X-ray powder diffractometer in transmission mode with a position sensitive detector using a copper $\mathrm{K}_{\alpha} \mathrm{X}$-ray source. Reflections were measured in steps of $0.02^{\circ}$ at a speed of $0.1^{\circ}$ per minute across the $2 \theta$ range 20 to $70^{\circ}$. Data were analyzed using 'STOE WinXPow' software.

Cell testing was performed using a commercial Probostat system (NorECS) and a custom gas handling system comprising mass flow controllers (Redy-smart, Vögtlin Instruments) (See Figure S2). Electrical measurements were performed in two-electrode mode without a reference electrode. Electrochemical characterization was performed by linear sweep potentiometry and electrochemical impedance spectroscopy (Model Modulab, Solartron) under a range of atmospheres. For $\mathrm{CO}_{2}$ electrolysis a small amount of $\mathrm{CO}$ was added to define the oxygen partial pressure and open circuit voltage (OCV). Tested cell microstructure was examined using scanning electron microscopy (InspectF, FEI) operated at $5 \mathrm{kV}$.

\section{Results and Discussion}

Previous studies ${ }^{34,36}$ have shown the cerium solubility limit in $\mathrm{SrTiO}_{3}$ to be related to the defect compensation mechanism which is highly dependent on the processing atmosphere. Under oxidizing conditions the donor is compensated by strontium vacancies, which corresponds to the general formula $\mathrm{Sr}_{1-1.5 \mathrm{x}} \mathrm{Ce}_{\mathrm{x}} \mathrm{TiO}_{3 \pm \delta}$. Figure 1 shows the $\mathrm{X}$-ray powder diffraction for the three compositions prepared in this study indicating the solubility limit lies between $x=0.2$ and 0.3 . This is lower than the solubility limit found by Ubic et al. of $\mathrm{x} \sim 0.40 .{ }^{37}$ Figure 2 shows the lattice parameter is consistent with the previous work of Cumming et al. ${ }^{34}$ and Subodh et al., ${ }^{38}$ including the $\mathrm{x}=0.3$ composition which suggests there are only very small amounts of residual $\mathrm{CeO}_{2}$. It may be that the samples containing higher $\mathrm{Ce}$ concentration required longer calcination times during synthesis. To test the performance in a solid oxide cell the $\mathrm{x}=0.2$ composition was chosen since it was the composition with the highest dopant level that was single phase. Samaria-doped ceria (SDC) was added to improve the ionic conductivity of the electrode as the oxygen ion conductivity in donor doped perovskites is known to be very low. ${ }^{39}$ Figure 3 shows the microstructure of a SCT-SDC (left) and a nickel impregnated SCTSDC (right) electrode. Both micrographs were recorded in backscatter mode. In the nickel-free sample (left) the SDC can clearly be seen as the brighter phase.

Preliminary testing was performed with and without nickel infiltration using cells that were not optimized and suffered several mechanical failures. A comparison of the $j-\mathrm{V}$ behavior is shown in the supplemental Figure S1. This preliminary study showed a large improvement in performance after the addition of a relatively small

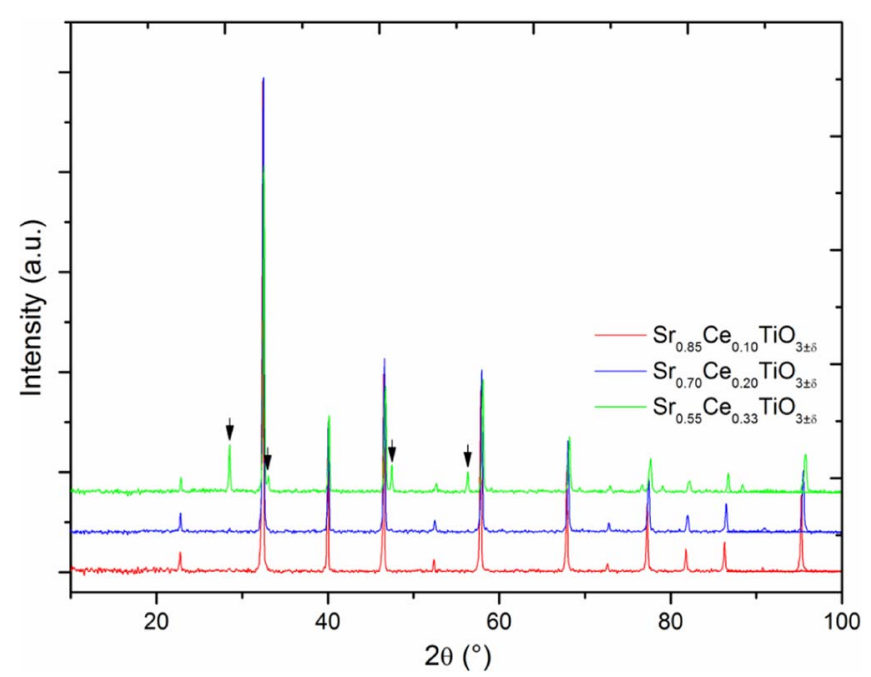

Figure 1. $\mathrm{XRD}$ patterns for $\mathrm{Sr}_{1-1.5 \mathrm{x}} \mathrm{Ce}_{\mathrm{x}} \mathrm{TiO}_{3}$ where $\mathrm{x}=0.1,0.2$ and $0.3 . \mathrm{CeO}_{2}$ (arrowed) is shown in the $\mathrm{x}=0.3$ composition.

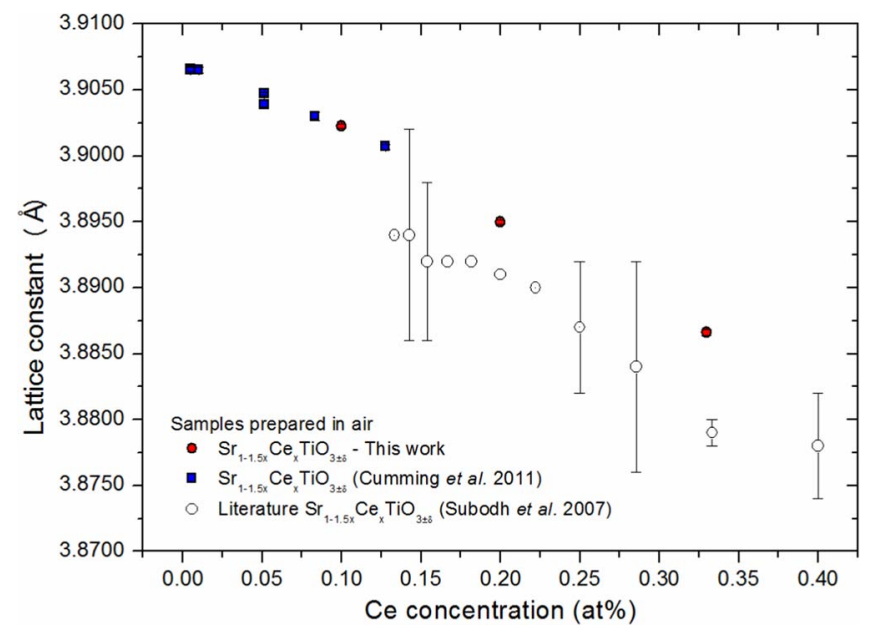

Figure 2. Lattice parameter versus cerium content in A-site deficient $\mathrm{SrTiO}_{3}$.

amount of nickel (estimated at 5-10 wt\%). This indicates a poor catalytic activity also seen in titanate-based electrodes in previous studies $^{25}$ is improved by the addition of nickel. Figure 3 shows that after nickel infiltration the ceramic scaffold structure is completely coated with nickel particles. Images were recorded after cell testing in which the cell had experienced temperatures up to $930^{\circ} \mathrm{C}$ during processing and $850^{\circ} \mathrm{C}$ during testing. Significant nickel agglomeration can be observed which is likely to have occurred while at high

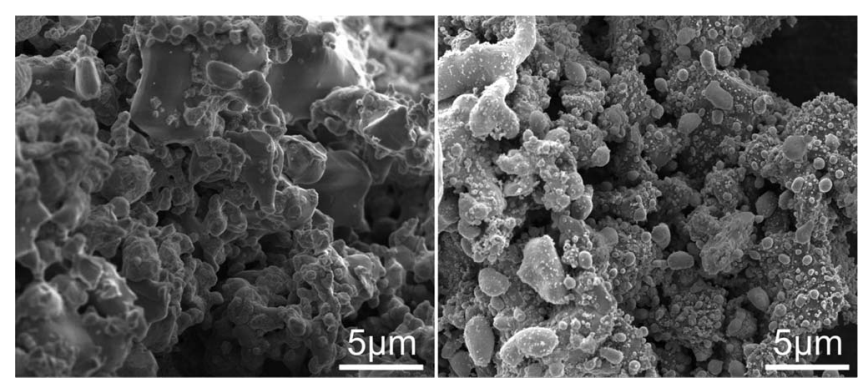

Figure 3. Secondary electron micrograph showing the comparison between SCT-SDC (left) and Ni-infiltrated SCT-SDC electrode (right). 


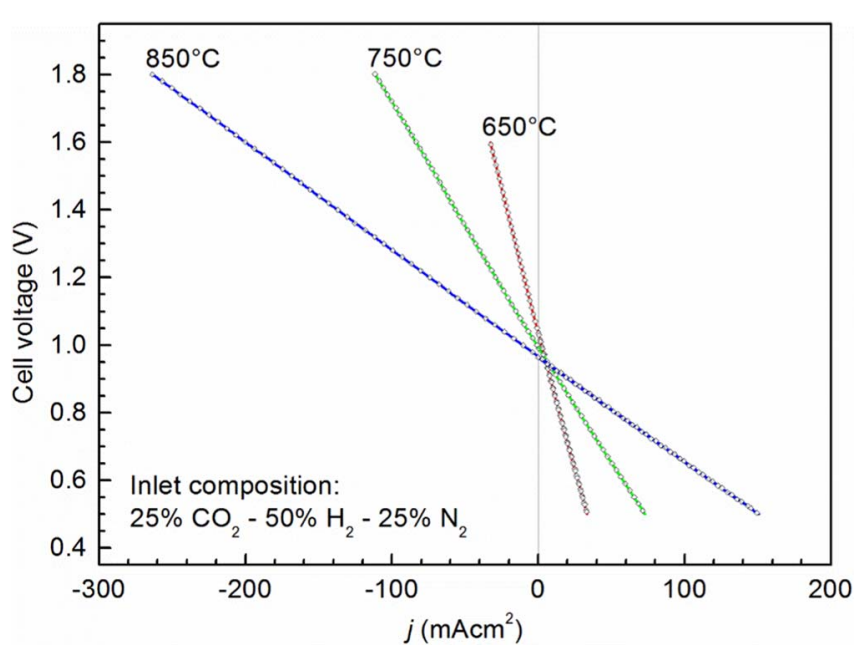

Figure 4. $j$ - $V$ data for cells running on a simulated co-electrolysis atmosphere at three temperatures. Cells show good reversible operation between fuel cell and electrolyzer mode.

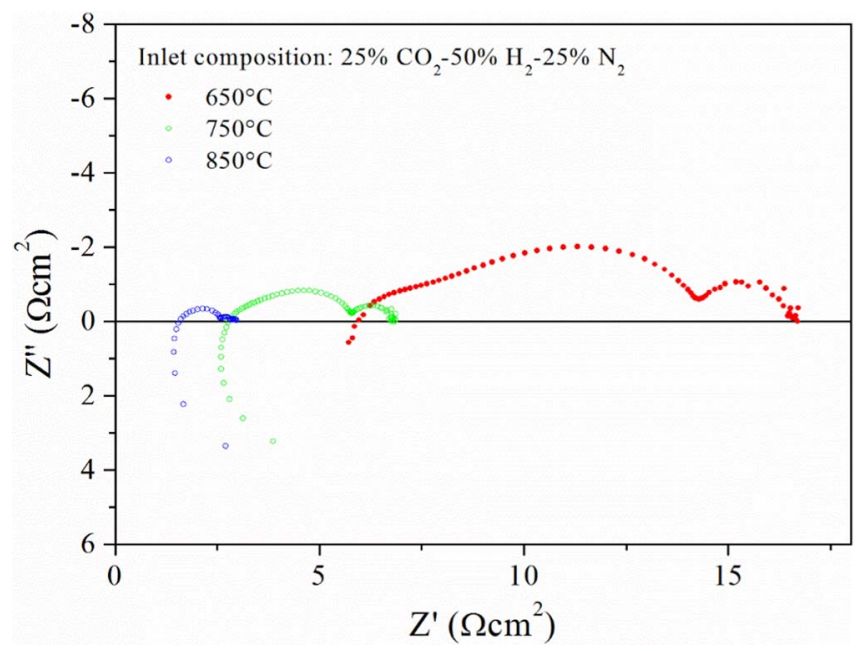

Figure 5. Complex impedance plots recorded at a range of temperatures operating on a simulated co-electrolysis atmosphere showing multiple, temperature-dependent processes occurring. Particularly encouraging is the decreasing size of the arc ascribed to the fuel electrode (at lower frequency) as the temperature increases.

temperature during testing. There is a wide range of nickel particle sizes, visually estimated to be between $\sim 150 \mathrm{~nm}-1 \mu \mathrm{m}$.

Figures 4 and 5 show the electrochemical performance of full, nickel-infiltrated cells in both fuel cell and electrolysis modes with the fuel electrode under a co-electrolysis atmosphere. The inlet feed for the fuel electrode contained only $\mathrm{CO}_{2}$ and $\mathrm{H}_{2}$ with a balance carrier of $\mathrm{N}_{2}$, which prevented problems with water condensation in up- stream pipework. At the temperatures of operation and in the presence of nickel the reverse water-gas shift reaction occurs rapidly to form a mixture suitable for co-electrolysis. Table I shows the equilibrium composition at the three testing temperatures along with the measured open circuit voltage $(\mathrm{OCV})$. For co-electrolysis mixtures the theoretical OCV was calculated based on the hydrogen-water equilibrium. Theoretical OCV values for the steam equilibrium are remarkably similar to those measured for co-electrolysis mixtures (see Table I) which may suggest that steam electrolysis is the dominant reaction at $\mathrm{OCV}^{3}$ The $j-V$ behavior in Figure 4 shows particularly good reversibility between electrolysis and fuel cell operation and current density for the cell configuration used in this study (i.e. electrolyte supported).

Impedance spectroscopy (Figure 5) shows that, at lower temperature, the oxygen electrode as well as the fuel electrode both contribute to the overall cell resistance. This is not particularly surprising when operating at $650^{\circ} \mathrm{C}$ with a LSM composite electrode. Testing with a LSCF-based oxygen electrode, suitable for use at lower temperatures, could help determine the performance of the fuel electrode without a significant contribution from the oxygen electrode.

Figures 4 and 5 show there is clearly sufficient electronic conductivity provided by the combination of nickel and the mixed conducting scaffold. SCT is estimated to have an electronic conductivity in the range of $1-10 \mathrm{Scm}^{-1}$ under a reducing atmosphere. ${ }^{22}$ Even at the lower end of this estimation there should be enough electronic conductivity to allow efficient operation. ${ }^{1}$ Therefore, by combining a mixed conducting scaffold with highly catalytic particles, the advantages of a near fully ceramic electrode can be realized.

Using a low nickel content also has the advantage that the structural integrity of the electrode is kept intact even if there are oxidation events. This study does not directly investigate the redox properties of an infiltrated, mixed conducting electrode, however, it has shown to be remarkably good at dry $\mathrm{CO}_{2}$ electrolysis where the oxygen partial pressure is significantly higher than when there is hydrogen present, as was the case for the co-electrolysis atmosphere. The $j-V$ behavior, shown in Figure 6 and corresponding impedance spectra, shown in Figure 7, display highly temperature dependent cell performance. Figure 6 shows significant non-linear $j$ - $V$ behavior that suggests a complex reaction process for $\mathrm{CO}_{2}$ at the fuel electrode. Comparing the experimentally observed $\mathrm{OCV}$ s with theoretical values calculated (see Table I), assuming the reduction of $\mathrm{CO}_{2}$ to $\mathrm{CO}$, suggests that, at least at $\mathrm{OCV}$, there is no carbon formation. Table II presents the area specific resistances (ASR) of the cell during $\mathrm{CO}_{2}$ electrolysis. At $850^{\circ} \mathrm{C}$ the ASR decreases significantly above a threshold current density $(\sim 50$ $\mathrm{mAcm}^{-2}$ ) and is comparable to co-electrolysis. This type of non-linear $j$ - $V$ behavior has also been observed by Wang et al. ${ }^{40}$ for bi-metallic catalysts, where significant activation-type behavior was observed at low current density, for both pure nickel and, despite performance improvements, for nickel alloyed with iron. Conversely, studies using all ceramic $\left(\mathrm{La}_{0.75} \mathrm{Sr}_{0.25}\right)_{0.97} \mathrm{Mn}_{0.5} \mathrm{Cr}_{0.5} \mathrm{O}_{3-\delta}$ electrodes showed highly linear $j$ - $V$ behavior. ${ }^{41}$ This result is somewhat counterintuitive; the catalytic properties of the metals would be expected not to require activation and the all-ceramic electrodes would be expected to show poor catalytic activity. One possible explanation is that at high $\mathrm{CO}_{2}$ concentrations there is partial re-oxidation of nickel at the surface. The activation behavior observed in the $j$-V plot represents the reduction

Table I. Fuel-side equilibrium atmosphere compositions, measured and calculated OCV values.

Co-Electrolysis (inlet: $25 \% \mathrm{CO}_{2}-50 \% \mathrm{H}_{2}-25 \% \mathrm{~N}_{2}$ )

\begin{tabular}{llll}
$\begin{array}{l}\text { Temperature } \\
{\left[{ }^{\circ} \mathrm{C}\right]}\end{array}$ & $\begin{array}{l}\text { Equil. composition }[\mathrm{mol} \%] \\
\mathrm{H}_{2}-\mathrm{CO}-\mathrm{H}_{2} \mathrm{O}-\mathrm{CO}_{2}-\mathrm{N}_{2}\end{array}$ & $\begin{array}{l}\text { Measured } \\
{[\mathrm{mV}]}\end{array}$ & $\begin{array}{l}\text { Theoretical }^{\mathrm{a}} \\
{[\mathrm{mV}]}\end{array}$ \\
\hline 650 & $36-14-14-11-25$ & 1039 & 1025 \\
750 & $34-16-16-9-25$ & 990 & 988 \\
850 & $33-17-17-8-25$ & 963 & 950
\end{tabular}

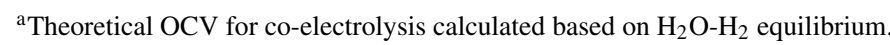

$\mathrm{CO}_{2}$ electrolysis (inlet: $2 \% \mathrm{CO}-98 \% \mathrm{CO}_{2}$ )

\begin{tabular}{cll}
\hline $\begin{array}{l}\text { Equil. composition } \\
{[\mathrm{mol} \%] \mathrm{CO}-\mathrm{CO}_{2}}\end{array}$ & $\begin{array}{l}\text { Measured } \\
{[\mathrm{mV}]}\end{array}$ & $\begin{array}{l}\text { Theoretical } \\
{[\mathrm{mV}]}\end{array}$ \\
\hline $2-98$ & 759 & 861 \\
$2-98$ & 687 & 796 \\
$2-98$ & 715 & 731
\end{tabular}




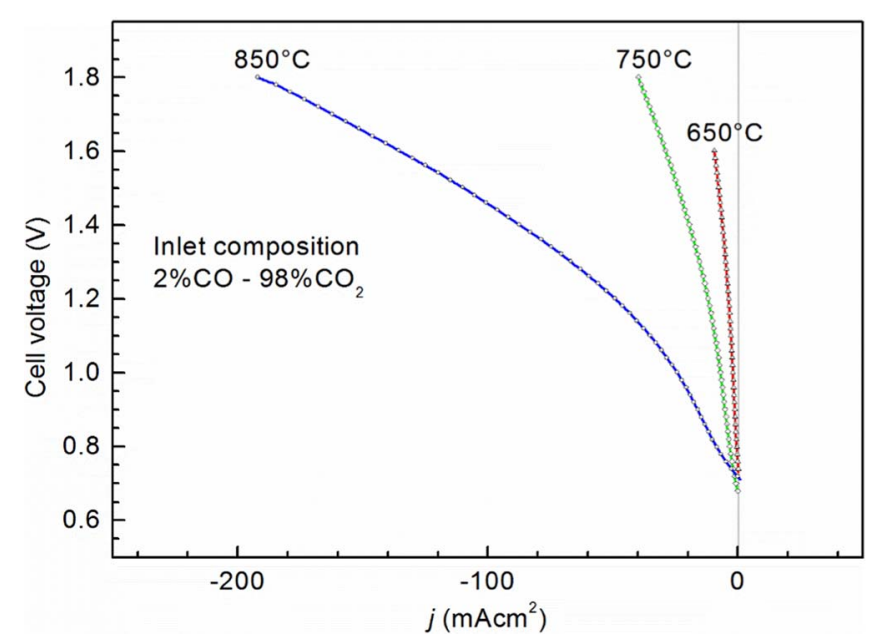

Figure 6. $j-V$ data for a $\mathrm{CO}_{2}-\mathrm{CO}$ mixture showing a degree of activation in electrolysis mode, even at $850^{\circ} \mathrm{C}$. Despite the higher initial ASR the cell was able to maintain a relatively high current density compared with the coelectrolysis case.

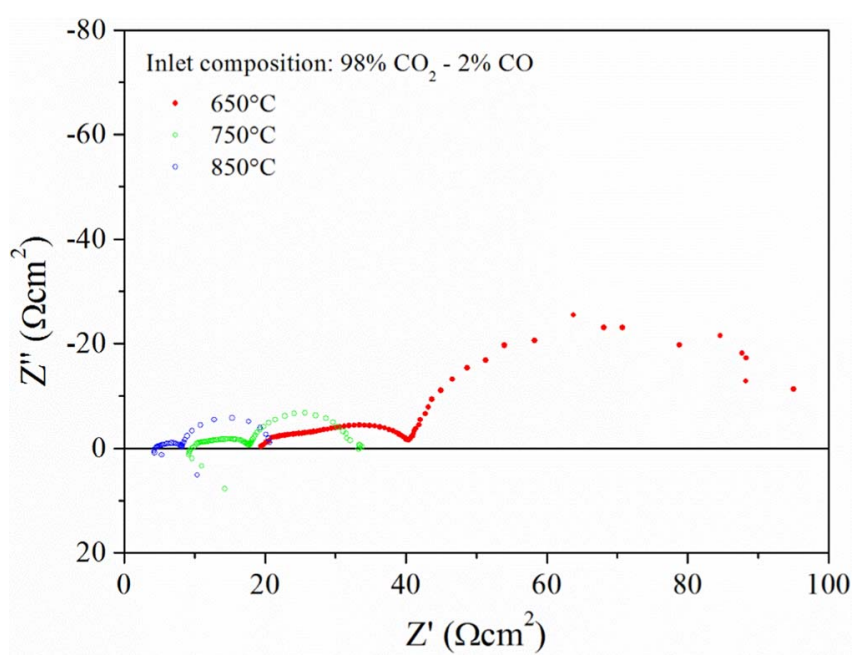

Figure 7. Complex impedance plots recorded at a range of temperatures operating on dry $\mathrm{CO}_{2}$. The main arc at higher frequency is ascribed to oxygen electrode processes and is comparable to the co-electrolysis case. Contributions from the fuel electrode and the series resistance are larger than for co-electrolysis which is not unusual.

\footnotetext{
Table II. Area specific resistance values for cells tested under various gas atmospheres and at different temperatures showing higher resistance toward $\mathrm{CO}_{2}$ electrolysis compared with coelectrolysis. ASR values for $\mathrm{CO}_{2}$ electrolysis for other doped titanate electrodes are also compared.
}

\begin{tabular}{lcccc} 
Temperature $\left[{ }^{\circ} \mathrm{C}\right] / \mathrm{ASR}\left[\Omega \mathrm{cm}^{2}\right]$ & $650^{\circ} \mathrm{C}$ & $750^{\circ} \mathrm{C}$ & $800^{\circ} \mathrm{C}$ & $850^{\circ} \mathrm{C}$ \\
\hline This work- Co-Electrolysis & 17.2 & 7.2 & & 3.12 \\
This work- $\mathrm{CO}_{2}$ electrolysis & 127.3 & 52.8 & & $4.60^{*}$ \\
& & & & 13.1 \\
Ref. $31 \mathrm{CO}_{2}$ electrolysis & & & $4.39^{*}$ & \\
Ref. $32 \mathrm{CO}_{2}$ electrolysis & & & $4.17^{*}$ & \\
Ref. $33 \mathrm{CO}_{2}$ electrolysis & & & $4.77^{*}$ &
\end{tabular}

*Values calculated from linear portion of polarization curve beyond the activation region $\left(>50 \mathrm{mAcm}^{-2}\right)$. of the surface oxide on the metal before the electrode becomes fully active toward $\mathrm{CO}_{2}$ electrolysis. Although this was not observed in the classical Ni-YSZ system studied by Ebbesen ${ }^{7}$ they did not publish the $j$ - $V$ curves for high $\mathrm{CO}_{2}$ concentrations. The shape of the $j-V$ curves in this study sits between the all-metallic and all-ceramic system when operating with high $\mathrm{CO}_{2}$ concentrations. Other titanate system show very similar results to this study (see Refs. 31-33 and Figure S3) but it is difficult to compare outright electrochemical performance from the very few reported instances and all examples are in non-optimized cell configurations. It is interesting to note that the Sc-doped and Ladoped (+nickel) titanates show identical performance. Other mixed conducting backbones with metallic nano-particles have also shown similar behavior. ${ }^{42}$

\section{Conclusions}

This work has demonstrated, for the first time, the applicability of Ce-doped strontium titanate as an excellent scaffold material to support catalyst nanoparticles for more active electrodes for high temperature electrolysis, combining the advantages of ceramic and metallic electrodes. Comparison of the cell performance in co-electrolysis and dry $\mathrm{CO}_{2}$ electrolysis modes showed that the titanate based electrode performed better in co-electrolysis mode, however, the electrode was also highly capable of direct, dry $\mathrm{CO}_{2}$ electrolysis showing increase in cell resistance due to an activation-type process at low current density but improved ASR at higher current. The total cell performance was limited by the cell configuration (i.e. electrolyte support) and oxygen electrode at temperatures below $750^{\circ} \mathrm{C}$. Despite this, cell performance was very similar to the few existing systems capable of dry $\mathrm{CO}_{2}$ electrolysis conditions and is a promising next-generation electrode material. There is significant scope for improved cell performance by optimized cell configuration and further work is needed to confirm the exact mechanism of $\mathrm{CO}_{2}$ reduction, in particular the activation effects, optimized catalysts chemistry and loading and stabilization of nano-sized catalyst decoration. Ce-doped titanate and other titanate system represent a new, exciting and flexible advance for carbon dioxide utilization and on-demand bespoke hydrocarbon production.

\section{Acknowledgments}

This work was carried out as part of the "4CU" programme grant, aimed at sustainable conversion of carbon dioxide into fuels, led by The University of Sheffield and carried out in collaboration with The University of Manchester, Queens University Belfast and University College London. The authors acknowledge gratefully the Engineering and Physical Sciences Research Council (EPSRC) for supporting this work financially (grant No EP/K001329/1).

\section{References}

1. Q. Fu, C. Mabilat, M. Zahid, A. Brisse, and L. Gautier, Energy Environ Sci, 3, 1382 (2010).

2. J. E. O'Brien, M. G. McKellar, C. M. Stoots, J. S. Herring, and G. L. Hawkes, Int J Hydrogen Energy, 34, 4216 (2009).

3. C. M. Stoots, J. E. O'Brien, J. S. Herring, and J. J. Hartvigsen, J Fuel Cell Sci Technol, 6 (2009).

4. S. D. Ebbesen, C. Graves, and M. Mogensen, Int J Green Energy 6, 646 (2009).

5. C. Graves, S. D. Ebbesen, and M. Mogensen, Solid State Ionics, 192, 398 (2011).

6. M. Chen, J. V. T. Høgh, J. U. Nielsen, J. J. Bentzen, S. D. Ebbesen, and P. V. Hendriksen, Fuel Cells, 13, 638 (2013).

7. S. D. Ebbesen and M. Mogensen, J Power Sources, 193, 349 (2009).

8. A. Atkinson, S. Barnett, R. J. Gorte, J. T. S. Irvine, A. J. Mcevoy, M. Mogensen, S. C. Singhal, and J. Vohs, Nature Materials, 3, 17 (2004).

9. T. Klemenso and M. Mogensen, J Am Ceram Soc, 90, 3582 (2007)

10. D. Sarantaridis and A. Atkinson, Fuel Cells, 7, 246 (2007).

11. D. Waldbillig, A. Wood, and D. G. Ivey, J Electrochem Soc, 154, B133 (2007).

12. L. Holzer, B. Iwanschitz, T. Hocker, B. Munch, M. Prestat, D. Wiedenmann, U. Vogt, P. Holtappels, J. Sfeir, A. Mai, and T. Graule, J Power Sources, 196, 1279 (2011).

13. D. Simwonis, F. Tietz, and D. Stover, Solid State Ionics, 132, 241 (2000).

14. Y. Matsuzaki and I. Yasuda, Solid State Ionics, 132, 261 (2000).

15. G. J. Offer, J. Mermelstein, E. Brightman, and N. P. Brandon, J Am Ceram Soc, 92, 763 (2009).

16. S. I. Lee, J. M. Vohs, and R. J. Gorte, J Electrochem Soc, 151, A1319 (2004). 
17. S. I. Lee, K. Ahn, J. M. Vohs, and R. J. Gorte, Electrochemical and Solid State Letters, 8, A48 (2005).

18. H. S. Spacil, United States Pat. No. 3,503,809, 1970.

19. H. P. He, R. J. Gorte, and J. M. Vohs, Electrochemical and Solid State Letters, 8 , A279 (2005).

20. S. An, C. Lu, W. L. Worrell, R. J. Gorte, and J. M. Vohs, Solid State Ionics, 175, 135 (2004).

21. E. V. Tsipis and V. V. Kharton, J Solid State Electr, 12, 1367 (2008).

22. J. C. Ruiz-Morales, J. Canales-Vazquez, C. Savaniu, D. Marrero-Lopez, W. Z. Zhou, and J. T. S. Irvine, Nature, 439, 568 (2006)

23. H. Zhao, F. Gao, X. Li, C. Zhang, and Y. Zhao, Solid State Ionics, 180, 193 (2009).

24. M. R. Pillai, I. Kim, D. M. Bierschenk, and S. A. Barnett, J Power Sources, 185, 1086 (2008)

25. A. M. Hussain, J. V. T. Hogh, W. Zhang, P. Blennow, N. Bonanos, and B. A. Boukamp, Electrochimica Acta, 113, 635 (2013).

26. A. M. Hussain, J. V. T. Hogh, T. Jacobsen, and N. Bonanos, Int J Hydrogen Energy, 37, 4309 (2012).

27. C. Arrive, T. Delahaye, O. Joubert, and G. Gauthier, J Power Sources, 223, 341 (2013).

28. G. Tsekouras, D. Neagu, and J. T. S. Irvine, Energy Environ Sci, 6, 256 (2013).

29. L. M. Yang, K. Xie, S. S. Xu, T. S. Wu, Q. Zhou, T. Xie, and Y. C. Wu, Dalton Transactions, 43, 14147 (2014).
30. J. Zhang, K. Xie, Y. Zhang, L. M. Yang, G. J. Wu, Q. Q. Qin, Y. X. Li, and Y. C. Wu, Rsc Advances, 4, 22697 (2014).

31. L. M. Yang, K. Xie, L. Wu, Q. Q. Qin, J. Zhang, Y. Zhang, T. Xie, and Y. C. Wu, Phys Chem Chem Phys, 16, 21417 (2014).

32. L. Gan, L. Ye, S. Tao, and K. Xie, Phys Chem Chem Phys, 18, 3137 (2016).

33. W. T. Qi, Y. Gan, D. Yin, Z. Y. Li, G. J. Wu, K. Xie, and Y. C. Wu, Journal of Materials Chemistry A, 2, 6904 (2014).

34. D. J. Cumming, J. A. Kilner, and S. Skinner, J Mater Chem, 21, 5021 (2011).

35. D. J. Cumming, V. V. Kharton, A. A. Yaremchenko, A. V. Kovalevsky, and J. A. Kilner, J Am Ceram Soc, 94, 2993 (2011).

36. C. E. Bamberger, T. J. Haverlock, S. S. Shoup, O. C. Kopp, and N. A. Stump, Journal of Alloys and Compounds, 204, 101 (1994).

37. R. Ubic, G. Subodh, D. Gout, M. T. Sebastian, and T. Proffen, Chem Mater, 21, 4706 (2009).

38. G. Subodh, J. James, M. T. Sebastian, R. Paniago, A. Dias, and R. L. Moreira, Chem Mater, 19, 4077 (2007).

39. R. Moos and K. H. Hardtl, J Am Ceram Soc, 80, 2549 (1997).

40. S. Wang, A. Inoishi, J. E. Hong, Y. W. Ju, H. Hagiwara, S. Ida, and T. Ishihara, Journal of Materials Chemistry A, 1, 12455 (2013).

41. X. Yue and J. T. S. Irvine, Electrochem Solid St, 15, B31 (2012)

42. J. Zhang, K. Xie, Y. Zhang, L. Yang, G. Wu, Q. Qin, Y. Li, and Y. Wu, RSC Advances, 4, 22697 (2014) 